\title{
Taxonomic Evaluation of Fifteen Species of Ipomoea L. (Convolvulaceae) from South-Western Nigeria using Foliar Micromorphological Characters
}

\author{
Abayomi Ezekiel FOLORUNSO \\ Obafemi Awolowo University, Department of Botany, Ile-Ife, Nigeria; afolorun@oauife.edu.ng
}

\begin{abstract}
Foliar micromorphological study was carried out on I. triloba, I. eriocarpa, I. alba, I. hederifolia, I. muricata, I. intrapilosa, I. asarifolia, I. batatas, I. aquatica, I. mauritiana, I. carnea, I.involucrata, I. nil, I. heterotricha and I. obscura to determine the patterns of variation in their epidermal characteristics and search for useful and stable anatomical characters for the identification of the species. Leaf epidermal features that provided useful specific distinctions are cell shape, anticlinal wall pattern, stomata shape, stomata type, trichome, cuticular striations, crystal, granular periclinal wall, stomata size, stomata index, scale and tannin. The characters revealed interrelationships among the Ipomoea species and also suggest their monophyly.
\end{abstract}

Keywords: characters, epidermal, Ipomoea, leaf, micromorphology

\section{Introduction}

Ipomoea is an exceptionally large and diverse genus in the family Convolvulaceae, it consists of about 600 species in strict and traditional concepts of the group (Austin and Huáman, 1996) or up to 1000 species in recent phylogenetic conceptions of the group (Manos et al., 2001; Miller et al., 2002; Wilkin, 1999). It is known that 38 species have been reportedly found in West Africa of which 30 have been recognized present in Nigeria. These species are commonly found in the Southern region, a few are found in the Northern location in the Savanna zones (Hutchinson and Dalziel, 1963). Ipomoea are good flagship species and possible good environmental indicator's (Gill, 1988). Ipomoea species are generally of vital economic importance ranging from ornamental, medicinal to culinary value.

Ipomoea species are highly variable in nature, most especially in Nigeria where they have received little attention when compared with the species from other countries and this has led to the description of intraspecific species. The high variability in Ipomoea species has created identification problems, a better system of classification and delimitation of the species using anatomical and biochemical characters is desirable. Previous works in the family revealed that pollen characteristics have been used as important criteria for generic delimitation. Spinose pollen of Ipomoea has been used to separate it from related genera, like Meremia and Operculina which have smooth pollen (Olorode, 1984). Shinner (1965) exploited the pollen character together with fruiting materials to dump both Meremia and Operculina into Ipomoea. However, gross similarities in the pollen characteristics of the different species of Ipomoea have been reported by Vij and Sachdeva
(1975), thus pollen characteristics cannot be used for species delimitation.

The objectives of this present work are to determine the patterns of variation in epidermal characteristics and use the foliar anatomical characters in the identification and classification of the Ipomoea species.

\section{Materials and methods}

Fresh leaves of fifteen species of Ipomoea namely $I$. triloba, I. eriocarpa, I. alba, I. hederifolia, I. muricata, I. intrapilosa, I. asarifolia, I. batatas, I. aquatica, I. mauritiana, I. carnea, I. involucrata, I. nil, I. heterotricha, I. obscura were collected from different locations in Obafemi Awolowo University Campus ( $7^{\circ} 47^{\prime} \mathrm{N}, 4^{\circ} 57^{\prime} \mathrm{E}$ ), Osun State, South West Nigeria. Species identification and confirmation was done at the Herbarium (IFE) in Obafemi Awolowo University Campus and Forestry Research Institute of Nigeria Herbarium (FHI), Ibadan. Voucher specimens were deposited in these herbaria.

Portions of the leaves were taken from the median part (midway between the tip and the base) from ten accessions of each species. These were put into Jeffrey's maceration mixture (10\% chromic acid and concentrated hydrochloric acid) and kept in oven at $60^{\circ} \mathrm{C}$ for about 15 minutes. Each sample was then washed thoroughly in 5 changes of water.

The adaxial and abaxial epidermis were separated by means of dissecting needle and forceps. The epidermal surfaces were stained in $1 \%$ safranin $O$ for about five minutes, washed with 4 changes of water to remove excess stain and then temporary mounts were made in $25 \%$ glycerol. Stomatal index was calculated according to Dilcher (1974). 
All processed materials were preserved in 50\% ethyl alcohol until when required. Photomicrographs of slides were taken with Amscope MT microscope camera version 3.001 attached to a light microscope. All measurements were made with the aid of ocular micrometer and final figure obtained with ocular constant.

\section{Results}

There are anatomical variations among the fifteen species of Ipomoea studied, and the characteristics of leaf epidermis of the Ipomoea are listed in Tab. 1 and 2. Light microscopic features of both abaxial and adaxial leaf surfaces are illustrated in Fig. 1 and 2.
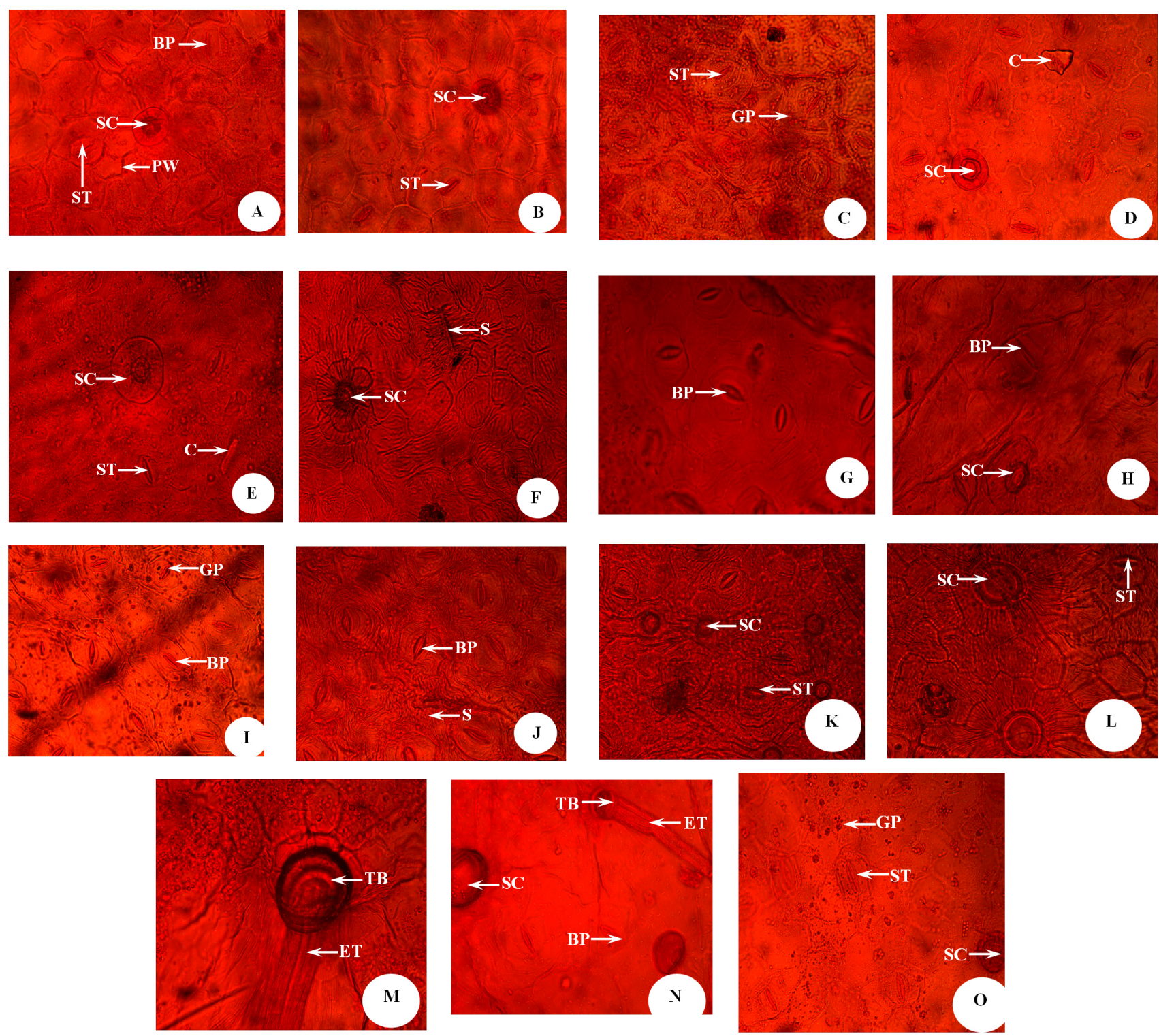

Fig. 1. Adaxial surface of Ipomoea species. A) I. triloba, B) I. eriocarpa, C) I. alba, D) I. hederifolia, E) I. muricata, F) I. intrapilosa, G) I. asarifolia, H) I. batatas, I) I. aquatica, J) I. mauritiana, K) I. carnea, L) I. involucrata, M) I. nil, N) I. heterotricha, O) I. obscura.; $\mathrm{BP}=$ Brachyparacytic stoma, $\mathrm{SC}=$ Scale, $\mathrm{PW}=$ Periclinal wall, $\mathrm{ST}=$ Stoma, $\mathrm{GP}=$ Granular periclinal wall, $\mathrm{C}=$ Crystal, $\mathrm{S}=$ Striae, $\mathrm{TB}=$ Trichome base, $\mathrm{ET}=$ Eglandular trichome, Scale $=0.85 \mu \mathrm{m}$ 
158

I. nil, I. eriocarpa, I. muricata and I. heterotricha where the stomata are paracytic.

\section{Stomatal index}

On the abaxial surface, the highest stomata index was in I. involucrata with the lowest in I. nil. Similarly, on the adaxial surface, the highest stomatal index was in $I$. alba with the lowest in I. triloba.

\section{Stomatal size}

I. triloba has the largest stomatal size while I. mauritiana has the smallest stomatal size on the abaxial size. On the adaxial surface, I. eriocarpa has the largest stomatal size
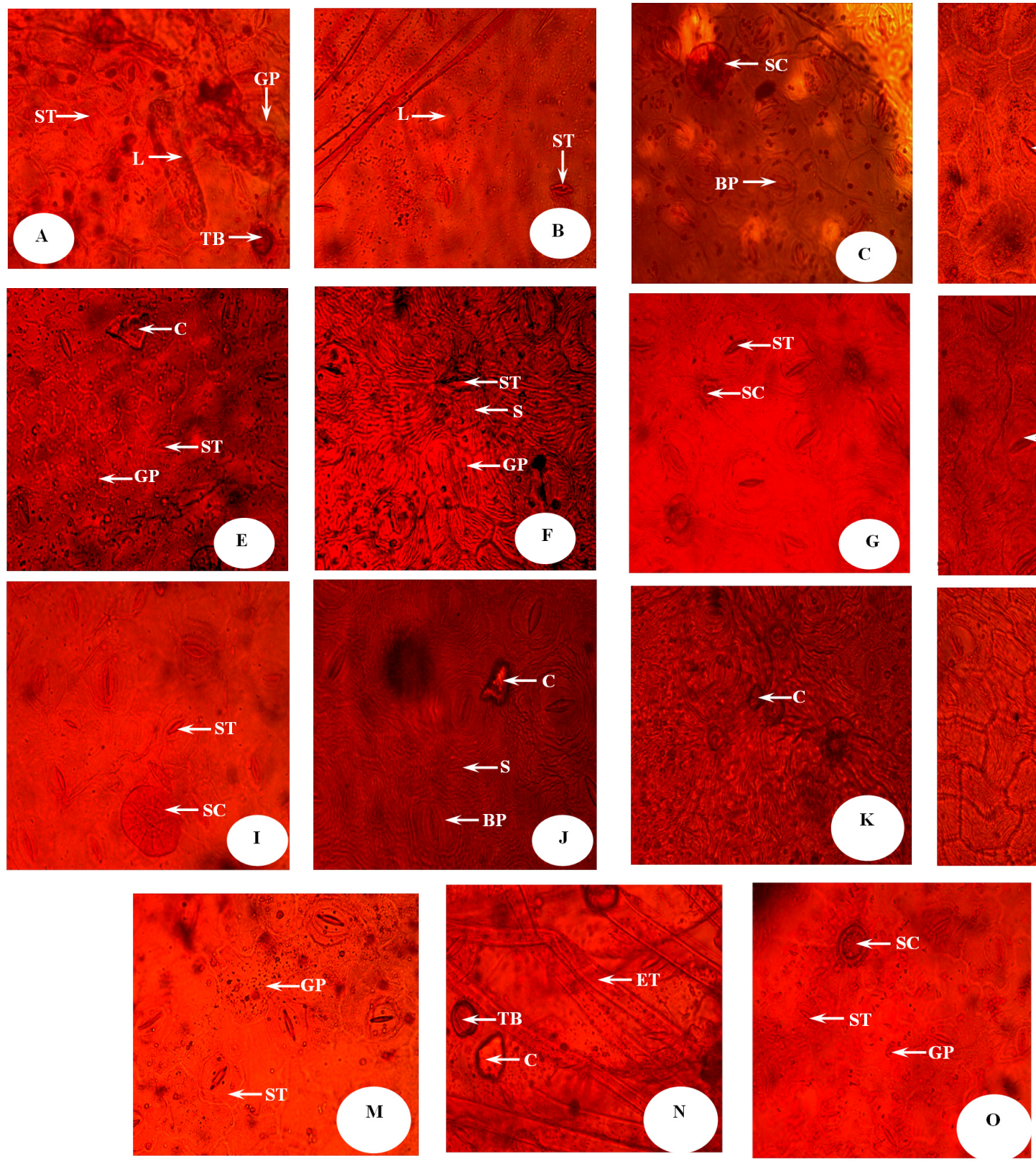

Fig. 2. Abaxial surface of Ipomoea species. A) I. triloba, B) I. eriocarpa, C) I. alba, D) I. hederifolia, E) I. muricata, F) I. intrapilosa, G) I. asarifolia, H) I. batatas, I) I. aquatica, J) I. mauritiana, K) I. carnea, L) I. involucrata, M) I. nil, N) I. heterotricha, O) I. obscura; $\mathrm{BP}=$ Brachyparacytic stoma, $\mathrm{SC}=$ Scale, $\mathrm{L}=$ Laticifer, $\mathrm{ST}=$ Stoma, $\mathrm{GP}=$ Granular periclinal wall, $\mathrm{C}=$ Crystal, $\mathrm{S}=$ Striae, $\mathrm{TB}=$ Trichome base, ET $=$ Eglandular trichome, Scale $=0.85 \mu \mathrm{m}$

while I. carnea and I. muricata are with the smallest stomatal size.

\section{Trichomes}

Glandular trichomes are present in I. batatas, I. carnea, I. intrapilosa and I. aquatica in the form of peltate scales but in the remaining species they are largely eglandular, simple and uniseriate.

\section{Cuticular striation}

There is cuticular striation on both surfaces of I. carnea, I. intrapilosa, I. asarifolia, I. mauritiana, I. aquatica and I. involucrata, the other species have no cuticular striation.
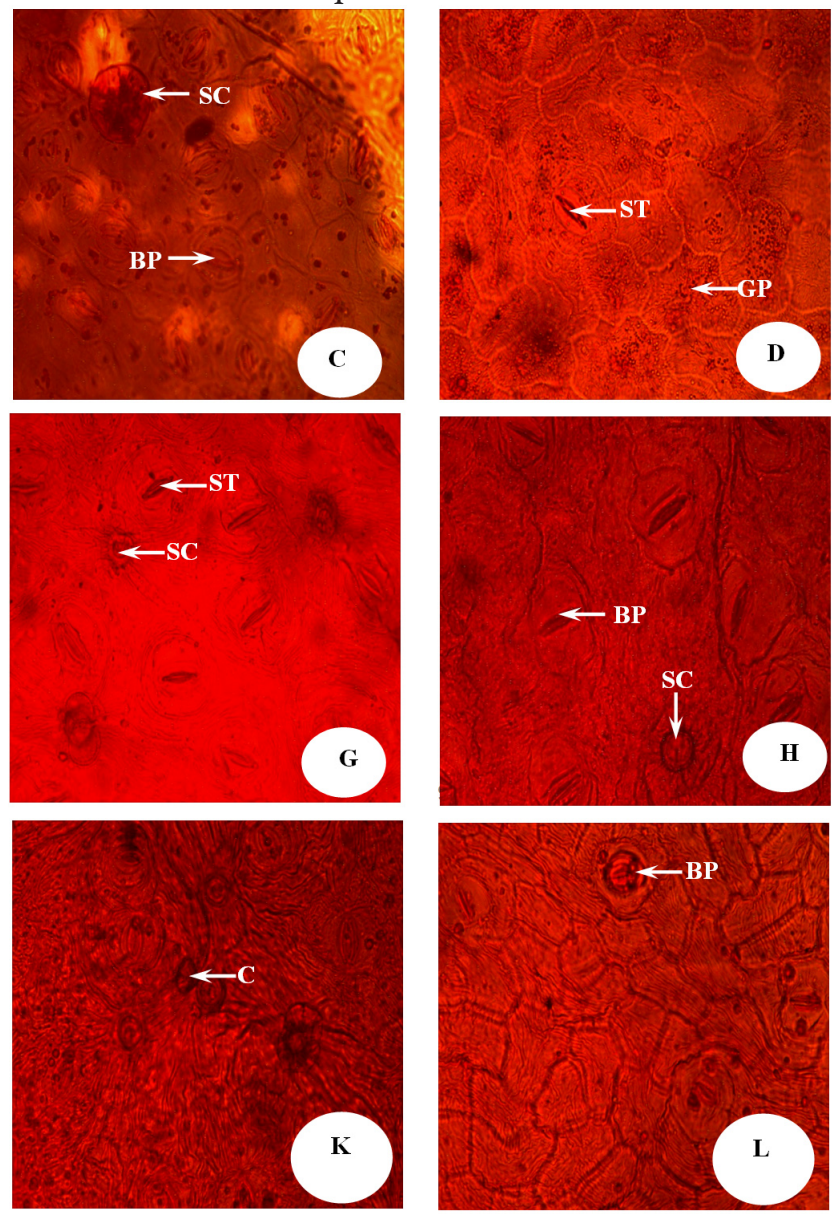
Tab. 1. Adaxial epidermal features of the South Western Nigerian Ipomoea species

\begin{tabular}{|c|c|c|c|c|c|c|c|c|c|c|c|c|c|c|c|}
\hline $\begin{array}{c}\text { Species/ } \\
\text { Characters }\end{array}$ & $\mathrm{CSH}$ & AWP & SSH & ST & $\mathrm{TR}$ & $\mathrm{C}$ & $\mathrm{T}$ & CST & SG & SC & GP & $\mathrm{L}$ & $\mathrm{CS}(\mathrm{L} / \mathrm{W})$ & SS & SI \\
\hline I. triloba & Polygonal & Straight & Elliptic & Brachyparacytic & Eglandular & - & - & + & - & + & - & - & $3.93-6.07 / 1.79-4.99$ & $2.68-10.20$ & $1.51-3.50$ \\
\hline I. eriocarpa & Polygonal & Straight & Elliptic & Paracytic & Eglandular & + & - & - & - & + & + & + & $2.87-3.93 / 1.07-2.14$ & $4.28-26.99$ & $20.00-29.37$ \\
\hline I. alba & Irregular & Straight & Circular & Brachyparacytic and Paracytic & Eglandular & - & + & - & - & + & + & - & $3.57-6.07 / 2.14-3.93$ & $1.28-4.08$ & $26.53-42.86$ \\
\hline I. hederifolia & Irregular & Wavy & Elliptic & Paracytic & Eglandular & + & - & - & - & + & + & - & $2.50-3.21 / 0.71-2.14$ & $1.53-4.59$ & $13.9-22.5$ \\
\hline I. muricata & Irregular & Wavy & Elliptic & Paracytic & Eglandular & + & - & - & - & + & + & - & $5.36-11.78 / 1.79-5.00$ & $0.43-2.50$ & $26.53-38.54$ \\
\hline I. intrapilosa & Rectangular to polygonal & Wavy & Elliptic & Brachyparacytic & Glandular & + & + & + & - & + & - & - & $3.57-6.07 / 1.79-2.86$ & $1.57-3.86$ & $13.79-16.67$ \\
\hline I. asarifolia & Polygonal & Straight & Elliptic & Brachyparacytic & Eglandular & + & - & + & - & + & + & - & $1.07-2.50 / 0.71-2.14$ & $1.78-8.03$ & $9.47-19.62$ \\
\hline I. batatas & Rectangular to polygonal & Straight to wavy & Oval & Brachyparacytic & Glandular & + & + & - & + & + & + & - & $3.93-8.21 / 1.79-3.57$ & $3.93-6.93$ & $16.22-20.00$ \\
\hline I. aquatic & Irregular & Wavy & Elliptic & Brachyparacytic & Glandular & + & + & + & - & + & - & - & $3.57-8.21 / 1.43-5.36$ & $2.29-17.21$ & $18.93-24.40$ \\
\hline I. mauritiana & Irregular & Wavy & Elliptic & Brachyparacytic & Eglandular & + & - & + & - & + & + & - & $5.00-7.50 / 1.43-4.28$ & $1.07-3.21$ & $32.54-33.06$ \\
\hline I. carnea & Rectangular to polygonal & Straight to wavy & Oval & Brachyparacytic & Glandular & + & - & + & - & + & + & - & $2.50-4.64 / 1.07-2.14$ & $0.43-2.78$ & $12.50-16.91$ \\
\hline I. involucrata & Rectangular to polygonal & Straight & Circular & Brachyparacytic & Absent & + & - & + & - & + & + & - & $3.57-5.36 / 1.79-3.21$ & $1.91-6.88$ & $23.05-36.99$ \\
\hline I. nil & Irregular & Wavy & Elliptic & Brachyparacytic/Paracytic & Eglandular & + & - & - & - & + & + & - & $2.14-4.64 / 0.71-1.79$ & $2.04-6.12$ & $6.98-17.97$ \\
\hline I. heterotricha & Irregular & Wavy & Elliptic & Paracytic & Eglandular & + & - & - & - & + & - & - & $1.79-2.50 / 0.71-1.07$ & $4.46-15.42$ & $27.13-32.05$ \\
\hline I. obscura & Irregular & Wavy & Elliptic & Paracytic & Eglandular & + & - & - & - & + & + & - & $2.50-7.14 / 1.43-3.57$ & $2.68-5.20$ & $27.27-36.00$ \\
\hline
\end{tabular}

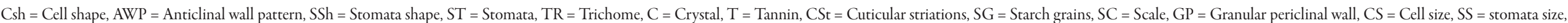
S.I $=$ Stomata index, $\mathrm{L}=$ Laticifer 
Tab. 2. Abaxial epidermal features of the South Western Nigerian Ipomoea species

\begin{tabular}{|c|c|c|c|c|c|c|c|c|c|c|c|c|c|c|c|}
\hline $\begin{array}{l}\text { Species/ } \\
\text { Characters }\end{array}$ & $\mathrm{CSH}$ & AWP & SSH & ST & $\mathrm{TR}$ & $\mathrm{C}$ & $\mathrm{T}$ & CST & SG & SC & GP & $\mathrm{L}$ & $\mathrm{CS}(\mathrm{L} / \mathrm{W})$ & SS & SI \\
\hline I. triloba & Rectangular to polygonal & Straight & Elliptic & Brachyparacytic & Eglandular & - & - & - & - & + & + & + & $4.28-6.07 / 1.79-3.57$ & $3.06-15.29$ & $24.28-30.00$ \\
\hline I. eriocarpa & Polygonal & Straight & Elliptic & Paracytic & Eglandular & + & - & - & - & + & + & + & $2.86-5.71 / 1.07-3.57$ & $1.79-9.42$ & $16.55-16.61$ \\
\hline I. alba & Polygonal to Irregular & Straight & Circular & Brachyparacytic and Paracytic & Absent & + & + & - & - & + & + & - & $2.49-5.36 / 1.43-2.49$ & $1.91-5.74$ & $29.59-44.59$ \\
\hline I. hederifolia & Polygonal & Wavy & Elliptic & Paracytic & Eglandular & + & - & - & - & + & + & - & $2.86-4.64 / 0.71-1.43$ & $2.04-5.61$ & $13.7-17.5$ \\
\hline I. muricata & Irregular & Wavy & Elliptic & Paracytic & Eglandular & + & - & - & - & + & + & - & $2.50-5.36 / 0.71-2.50$ & $0.75-3.43$ & $23.38-30.49$ \\
\hline I. intrapilosa & Rectangular to polygonal & Straight & Elliptic & Brachyparacytic & Glandular & + & - & + & - & + & + & - & $2.50-6.43 / 1.43-3.57$ & $0.86-3.00$ & $16.21-19.23$ \\
\hline I. asarifolia & Polygonal & Straight & Elliptic & Brachyparacytic & Eglandular & + & - & + & - & + & + & - & $1.07-3.21 / 0.71-1.43$ & $3.44-6.12$ & $11.07-22.06$ \\
\hline I. batatas & Rectangular to polygonal & Wavy & Oval & Brachyparacytic & Glandular & + & + & - & - & + & - & - & $3.57-10.71 / 1.43-2.50$ & $3.14-6.85$ & $12.41-19.84$ \\
\hline I. aquatic & Irregular & Wavy & Elliptic & Brachyparacytic & Glandular & + & + & + & + & + & - & - & $2.50-7.14 / 1.43-3.57$ & $2.04-10.71$ & $27.14-37.87$ \\
\hline I. mauritiana & Polygonal & Wavy & Elliptic & Brachyparacytic/Paracytic & Eglandular & + & - & + & - & + & + & + & $3.57-6.43 / 1.07-2.50$ & $0.57-2.14$ & $25.24-32.92$ \\
\hline I. carnea & Rectangular to polygonal & Wavy & Oval & Brachyparacytic & Glandular & + & - & + & - & + & + & - & $2.86-8.57 / 1.07-2.14$ & $1.43-4.86$ & $15.38-20.00$ \\
\hline I. involucrata & Rectangular to polygonal & Straight & Circular & Brachyparacytic & Absent & + & + & + & - & + & + & - & $3.21-4.99 / 1.79-3.57$ & $2.29-3.57$ & $32.34-45.79$ \\
\hline I. nil & Irregular & Wavy & Elliptic & Paracytic & Eglandular & + & - & - & - & - & + & - & $2.86-6.07 / 1.07-2.14$ & $3.06-7.65$ & $6.80-16.52$ \\
\hline I. heterotricha & Irregular & Wavy & Elliptic & Paracytic & Eglandular & + & - & - & - & + & - & - & $2.50-8.93 / 1.43-3.57$ & $2.04-10.71$ & $18.07-32.89$ \\
\hline I. obscura & Irregular & Wavy & Elliptic & Brachyparacytic & Glandular & + & + & - & + & - & + & - & $0.60-4.64 / 1.79-2.86$ & $1.27-10.32$ & $24.06-36.00$ \\
\hline
\end{tabular}

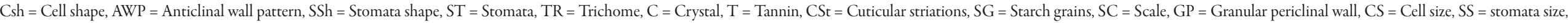

S.I. $=$ Stomata index, $\mathrm{L}=$ Laticifer 
Laticifer

Laticifer is present only in I. triloba, I. eriocarpa and I. mauritiana on the abaxial surface while it is absent on both surfaces in the other species of Ipomoea.

\section{Discussion}

The data recorded in this study showed that there are many anatomical variations between the 15 species of Ipomoea studied. Each species showed marked consistency for the anatomical characters examined. On the adaxial surface, the presence of rectangular to polygonal cell shape, straight to wavy anticlinal wall, oval stomatal shape, brachyparacytic stomata type, glandular trichome, granular periclinal wall, scale and crystal unit $I$. batatas and $I$. carnea. I. involucrata is more closely related to them except with the presence of circular stomatal shape, absence of trichome, scale and granular periclinal wall. $I$. hederifolia, I. muricata, I. heterotricha and I. obscura are closely related with the presence of irregular cell shape, wavy anticlinal wall, elliptic and paracytic stomata, eglandular trichomes except for some few characters which are different in them.

Stomata type separates the Ipomoea species into two groups. The presence of brachyparacytic stomata is diagnostic in I. batatas, I. carnea, I. intrapilosa, I. asarifolia, I. nil, I. mauritiana, I. aquatica, I. triloba, I. alba and I. involucrata, the remaining species have paracytic stomata type. As reported by Adedeji (2004), stomatal index is highly constant for a certain species and can be used for species delimitation. Similarly, Abdulrahaman and Oladele (2012) reported that the rate of transpiration affects stomata type and size, according to them, leaf having higher rate of transpiration are with larger stomata sizes than those having lower rate of transpiration. On the adaxial surface, I. alba has the highest stomatal index while I. triloba is with the lowest stomatal index. Stomatal size is not correlated with stomatal index in the species studied. For instance, I. eriocarpa has the largest stomata size and hence higher rate of transpiration while both I. carnea and I. muricata are with the smallest stomata size on the adaxial surface and therefore having the lowest rate of transpiration.

The findings in this work support previous studies where leaf anatomical characters have been used as a taxonomic tool (Adedeji, 2004; Akçin and Binzet, 2010; Ogundipe and Olatunji, 1991; Illoh, 1995; Ogundare and Saheed, 2012). The presence of cuticular striations delimit the Ipomoea species into two main groups, this is noticeable in I. carnea, I. intrapilosa, I, asarifolia, I. mauritiana, I. aquatica and I. involucrata. Cuticular striations are special architectural structures on the epidermal surfaces of these species and could be performing vital protective functions. The presence of a particular type of trichome can frequently delimit species, genera or even whole families (Metcalfe and Chalk, 1979). On the basis of trichome, the species fall into three groups; those with glandular trichomes are
I. batatas, I. carnea, I. intrapilosa, I. aquatica and I. obscura, the remaining species have eglandular trichomes except in I. involucrata where trichome is absent. This supports the view that trichomes are of considerable importance in comparative systematics of angiosperms (Theobald $e t$ al., 1979).

This study supports the observation of earlier worker that micromorphological characters and other epidermal characters could be employed for species delimitations.

\section{References}

Abdulrahaman AA, Oladele O (2012). Anatomical basis for optimal use of water for maintenance of three xerophytic plants. Not Sci Biol 4(2):53-58.

Adedeji O (2004). Leaf epidermal studies of Emilia Cass. (Senecionaea, Asteraceae) species in Nigeria. Bot Lithu 10(2):121133.

Akçin OE, Binzet R (2010). The micromorphological and anatomical properties of Onosma angustissimum Hausskn. \& Bornm. and O. cassium Boiss. (Boraginaceae). Bangladesh J Plant Taxon 17(1):1-8.

Austin DF, Huáman Z (1996). A synopsis of Ipomoea (Convolvulaceae) in the Americas. Taxon 29:501-502.

Dilcher KL (1974). Approaches to the identification of Angiosperm leaf remains. Bot Rev 40:2-157.

Gill LS (1988). Taxonomy of Flowering Plants. Africana-Fep Publishers Limited, 116-119 p.

Hutchinson J, Dalziel JM (1963). Flora of West Tropical African, $1^{\text {st }}$ edition By Hepper FN, 3:215-225.

Illoh HC (1995). Foliar epidermis and petiole anatomy of four species of Celosia L. in Nigeria. Feddes Reppert 106(12):15-23.

Manos PS, Miller RE, Wilkin P (2001). Phylogenetic analysis of Ipomoea, Argyreia, Stictocardia and Turbina suggests a generalized model of morphological evolution in morning glories. Syst Bot 26:585-602.

Metcalfe CR, Chalk L (1979). Anatomy of the Dicotyledons $2^{\text {nd }}$ Edition, Volume I, Oxford, Clarendon Press, 40-53 p.

Miller RE, Buckley TR, Manos PS (2002). An examination of the monophyly of morning glory taxa using Bayesian phylogenetic inference. Systematic Biology 51:740-753.

Ogundare CS, Saheed SA (2012). Foliar epidermal characters and petiole anatomy of four species of Citrus L. (Rutaceae) from South-Western Nigeria. Bangladesh J Plant Taxon $19(1): 25-31$.

Ogundipe OT, Olatunji OA (1991). The leaf anatomy of the species of Cochlospermum (Cochlospermaceae) in West Africa, Feddes Reppert 102(3-4):183-187.

Olorode O (1984). Taxonomy of West African Flowering Plants. Longman Group Ltd, London, 88-89 p.

Shinner LH (1965). Untypification for Ipomoea nil (L.). Taxon 14:231-234. 
162

Theobald JLW, Krahulic JL, Rollins RC (1979). Trichome description and classification, 40-53 p. In: Metcalfe CR, Chalk L (Eds.). Anatomy of the Dicotyledons, $2^{\text {nd }}$ Edition, Volume I, Oxford, Clarendon Press.
Vij SP, Singh S, Sachdeva VP (1975). Pollen grain studies in some North Indian Convolvulaceae. J Palynology 10(2):133-143.

Wilkin P (1999). A morphological cladistic analysis of the Ipomoeae (Convolvulaceae). Kew Bull 54:853-876.

Taxonomic Key for the identification of Ipomoea species studied

\begin{tabular}{|c|c|}
\hline Trichome glandular & I. batatas, I. carnea, I. intrapilosa, I. aquatica \\
\hline Stomata shape elliptic & I. intrapilosa, I. aquatica \\
\hline Cell shape irregular & I. aquatica \\
\hline Cell shape rectangular & I. intrapilosa \\
\hline Stomata shape oval & I. batatas, I. carnea \\
\hline Trichome present & I. batatas \\
\hline Trichome absent & I. carnea \\
\hline Trichome eglandular or absent & $\begin{array}{l}\text { I. involucrata, I. asarifolia, I. mauritiana, I. eriocarpa, I. triloba, I. alba, I. nil, } \\
\text { I. heterotricha, I. muricata, I. obscura, I. hederifolia }\end{array}$ \\
\hline Trichome absent & I. involucrata \\
\hline Trichome eglandular & $\begin{array}{l}\text { I. asarifolia, I. mauritiana, I. eriocarpa, I. triloba, I. alba, I. nil, I. heterotricha, } \\
\text { I. muricata, I. obscura, I. hederifolia }\end{array}$ \\
\hline Cuticular striation present & I. asarifolia, I. mauritiana \\
\hline Cell shape polygonal & I. asarifolia \\
\hline Cell shape irregular & I. mauritiana \\
\hline Cuticular striation absent & $\begin{array}{l}\text { I. eriocarpa, I. triloba, I. alba, I. nil, I. heterotricha, I. muricata, I. obscura, I. } \\
\text { hederifolia }\end{array}$ \\
\hline Cell shape polygonal & I. eriocarpa, I. triloba \\
\hline Stomata paracytic & I. eriocarpa \\
\hline Stomata Brachyparacytic & I. triloba \\
\hline Cell shape irregular & I. alba, I. nil, I. heterotricha, I. muricata, I. obscura, I. hederifolia \\
\hline Anticlinal wall straight & I. alba \\
\hline Anticlinal wall wavy & I. nil, I. heterotricha, I. muricata, I. obscura, I. hederifolia \\
\hline Stomata Brachyparacytic & I. nil \\
\hline Stomata Paracytic & I. heterotricha, I. muricata, I. obscura, I. hederifolia \\
\hline Stomata size above $5.20 \mu \mathrm{m}^{2}$ & I. heterotricha \\
\hline Stomata size below $5.20 \mu \mathrm{m}^{2}$ & I. muricata, I. obscura, I. hederifolia \\
\hline Stomata index above $38.00 \%$ & I. muricata \\
\hline Stomata index below $38.00 \%$ & I. obscura, I. hederifolia \\
\hline Epidermal cell length above $3.50 \mu \mathrm{m}$ & I. obscura \\
\hline Epidermal cell length below $3.50 \mu \mathrm{m}$ & I. hederifolia \\
\hline
\end{tabular}

